\title{
Changing the Face of Medicine in Canada with Dr. John Murray Last, Public Health Scholar and Emeritus Professor at the University of
} Ottawa

\author{
Glara Gaeun Rhee, BSc${ }^{1}$, Tharshika Thangarasa, BSc ${ }^{1}$ \\ ${ }^{1}$ Faculty of Medicine, University of Ottawa
}

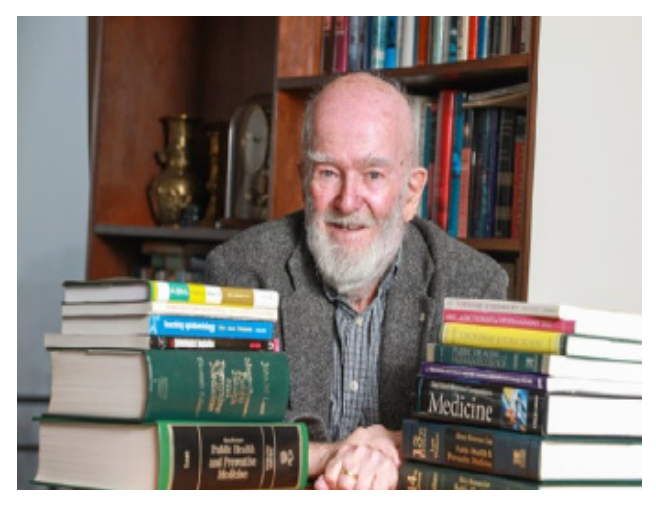

A B STR A C T

Dr. John Murray Last, MB BS, is an Emeritus Professor at the University of Ottawa. Having been born in Australia in 1926, and having studied and worked in Australia, England, the United States, and Canada, Dr. Last has developed tremendous knowledge surrounding healthcare around the world. Dr. Last is a scientist, teacher, successful author, and public health scholar. His books are now used in schools of public health worldwide. In addition to having developed the "iceberg concept", he has also served as a leader in the development of ethical standards for epidemiology and public health. In 2012, Dr. Last was admitted as an Officer of the Order of Canada to honour his contribution to the public health sciences.

\section{RÉ S U MÉ}

Dr. John Murray Last, MBBS, est un professeur émérite à I'Université d'Ottawa. Étant né en Australie en 1926, et ayant étudié et travaillé en Australie, en Angleterre, aux États-Unis, et au Canada. Dr. Last a acquis de prodigieuses connaissances quant aux soins de santé à travers le monde. Dr. Last est un scientifique, enseignant, auteur à succès, et un spécialiste de la santé publique. Ses livres sont actuellement utilisés dans des écoles de santé publique à l'échelle mondiale. En plus d'avoir mis au point le concept " d'iceberg ", il a aussi été un leader pour l'élaboration de normes d'éthiques en épidémiologie et santé publique. En 2012, Dr. Last a été nommé Officier de l'Ordre du Canada pour honorer sa contribution aux sciences de la santé publique.

\section{TELL US A BIT ABOUT YOURSELF: YOUR CAREER PATH, BACKGROUND IN HEALTHCARE, YOUR FORMER CLINICAL AND RESEARCH INTERESTS, AS WELL AS WHAT INSPIRED YOU TO PURSUE A CAREER IN PUBLIC HEALTH.}

When I completed my medical education at the University of Adelaide in 1949, I did not have a clue as to what I wanted to do at that time. But when I was in Australia and doing general practice for 5 years, I had the wonderful fortune of picking up a beautiful lady one day. When I picked her up, I told her that I could only drive her to the end of the road, but in that 10-minute drive, I decided that I wanted to learn more about her. To cut a long story short, she went her way and I went mine-but we wrote letters to each other for about 6 months. Eventually, she came back to Australia and we had a wonderful 55 years of married life together. She was my inspiration. Before meeting her I didn't know what I wanted to do-but through a combination of gaining maturity and my wife's gentle influence on shaping my values, I developed the drive to keep people healthy instead of waiting for them to get sick. This shaped my career thereafter-it influenced my decision to transition from general practice to a career in public health and preventive medicine.

This was also a time when the Royal College of General Practitioners was getting up and running in English-speaking countries. Around then, I was in considerable demand by many university departments all around the world that wanted to get their hands on family physicians who had the idea of trying to combine general practice and preventive medicine. It was great. It was a bit of a pity that, in order to learn epidemiology and do research work, I had to give up my general practice.

My career in public health really took off when I was given the opportunity to serve as one of the chief editors of a book entitled "Public Health and Preventive Medicine" [1]. I have been mainly at the University of Ottawa since 1969. 


\section{CAN YOU BRIEFLY TELL US ABOUT THE BOOK?}

The entire book, which has around 1200 pages, can be summarized in one basic concept, the five key principles for keeping people healthy: (1) enhance immunity, (2) make the environment safe (e.g., get rid of hazards in the environment, including toxic chemicals and dangerous pathogens), (3) promote sensible nutrition (e.g., eat the right kinds of food), (4) encourage sensible behavior, and (5) discourage unhealthy behaviors, like smoking cigarettes. This last point is especially interesting. Smoking was a huge problem when I was a medical student. Almost everyone, including my professor, would have a cigarette dangling from their lips, smoke drifting into their eyes-it was a remarkable site. Now, smoking rates have dropped substantially. This is largely thanks to the emphasis that has been placed on education and preventive medicine.

\section{CAN YOU TELL US A LITTLE BIT ABOUT THE "ICEBERG CONCEPT" AND HOW YOU CAME UP WITH IT?}

The iceberg concept was born in the 1960s. I had received a travel scholarship from Australia to work with the most exciting man in London-Jeremiah (Jerry) Morris. He was one of three eminent epidemiologists in public health at the time. He had the remarkable idea of differentiating the various stages of symptomatic disease from the precursors of disease.

Imagine an iceberg. When you observe an iceberg in the sea, you only really see $1 / 7$ th or $1 / 9$ th of it. The population in any general practice is like an iceberg where only a little bit sticks out on the surface. The part of iceberg above the surface represents the symptomatic and diagnosed instances of various diseases in the population. Below the surface are the diseased people who are asymptomatic. It is essentially an analogy used to describe the disease pattern in the community [2].

\section{CAN YOU DEFINE PREVENTIVE MEDICINE AND PERSONAL- IZED MEDICINE FOR US? WHAT DOES IT MEAN TO YOU?}

I defined preventive medicine in my book as "the specialized branch of clinical and medical practice devoted to promoting health and preventing disease and premature disability" [3]. Activities within preventive medicine can be targeted at the level of an individual or the population at large.

Personalized medicine is what a physician does with one patient at a time, whereas public health specialists essentially do the same thing with the entire population. For me, personalized medicine is like monitoring individual people in the population to identify signs that indicate something is coming apart or not going as well as it should. Essentially, the goal is to identify what that something is in each individual person and fix it before it gets worse.

There were times when we used to visit people in their own homes. It is a pity that this does not happen as often today. It is one of the most interesting and rewarding aspects of medical practice. You get to treat the patient instead of waiting for them to get sick and come to the hospital. Encourage your teachers to visit sick people in their own homes.

\section{CAN YOU TELL US A LITTLE BIT ABOUT HOW SOCIETY'S AT- TITUDE TOWARDS PREVENTIVE MEDICINE HAS CHANGED OVER THE YEARS?}

This moves into something that I am passionate about-values. Most caring parents, especially caring mothers, can identify what I am about to talk about now. They passionately care about keeping their children healthy, and will do anything to accomplish this. They are sure to get their children immunized, make sure they have the right diet, eat the right kinds of foods, make sure they get enough exercise, keep them away from places where they are likely to get infected. This maternal instinct encompasses the values of preventive medicine. This has remained constant over the years. What has changed is that with advancement in our knowledge, we are better able to promote practices that improve public health.

\section{GIVEN THE RECENT INFLUX OF REFUGEES FROM SYRIA, WHAT DO YOU THINK CANADA SHOULD FOCUS ON IN TERMS OF PREVENTIVE MEDICINE MOVING FORWARD?}

Interestingly, when I was a general practitioner in Adelaide around the 1950s, I was in the front line dealing with the first postwar influx of 'New Australian' immigrants. These included high proportions of refugees and displaced people who had lost their country and most of their family members-like the refugees from Syria, but worse: more of them, often severely traumatized, emotionally damaged. That's what dragged me from a contented life in general practice into public health sciences and preventive medicine. In short, I definitely think Canada should invest resources into ensuring that the unique health needs of this population are met.

\section{ACKNOWLEDGEMENTS}

The authors would like to thank Dr. John Murray Last for taking time out of his day and allowing us the privilege of interviewing him. For further information about Dr. Last and his published work, please visit his Wikipedia page or his personal blog at http://lastswords.blogspot.ca. 


\section{Interview}

\section{REFERENCES}

1. Last JM, Wallace RB. Maxcy-Rosenau-Last Public Health \& Prevantive Medicine. Journal of Public Health Policy. In: Last JM, ed. Vol 7. 13th ed. CT: Appleton\&Lange; 1986.

2. Last JM, Adelaide DP. The iceberg: 'completing the clinical picture' in general practice. Int J Epidemiol. 2013;42(6):1608-13.

3. Last JM. A dictionary of epidemiology. Vol 141. NY: Oxford university press; 2001. 